\title{
Three pillars of sustainability: in search of conceptual origins
}

\author{
Ben Purvis $^{1}$ (D) Yong Mao ${ }^{1,2} \cdot$ Darren Robinson ${ }^{1,3}$
}

Received: 1 December 2017 / Accepted: 23 August 2018/ Published online: 3 September 2018

(C) The Author(s) 2018

\begin{abstract}
The three-pillar conception of (social, economic and environmental) sustainability, commonly represented by three intersecting circles with overall sustainability at the centre, has become ubiquitous. With a view of identifying the genesis and theoretical foundations of this conception, this paper reviews and discusses relevant historical sustainability literature. From this we find that there is no single point of origin of this three-pillar conception, but rather a gradual emergence from various critiques in the early academic literature of the economic status quo from both social and ecological perspectives on the one hand, and the quest to reconcile economic growth as a solution to social and ecological problems on the part of the United Nations on the other. The popular three circles diagram appears to have been first presented by Barbier (Environ Conserv 14:101, doi: 10.1017/s0376892900011449, 1987), albeit purposed towards developing nations with foci which differ from modern interpretations. The conceptualisation of three pillars seems to predate this, however. Nowhere have we found a theoretically rigorous description of the three pillars. This is thought to be in part due to the nature of the sustainability discourse arising from broadly different schools of thought historically. The absence of such a theoretically solid conception frustrates approaches towards a theoretically rigorous operationalisation of 'sustainability'.
\end{abstract}

Keywords Sustainable development · Conceptual review · Historical origins · Triple bottom line $\cdot$ History of sustainability

\section{Introduction}

The last 20 years have witnessed a surge in publications on 'sustainability', to the extent where 'sustainability science' is often seen as a distinct field (Kates et al. 2001; Komiyama and Takeuchi 2006; Schoolman et al. 2012; Kajikawa et al. 2014). Yet despite this, 'sustainability' remains an open concept with myriad interpretations and context-specific understanding.

One particularly prevalent description of 'sustainability' employs three interconnected 'pillars' (Basiago 1999; Pope et al. 2004; Gibson 2006; Waas et al. 2011; Moldan et al.

Handled by Michael O'Rourke, Michigan State University, USA.

Ben Purvis

benjamin.purvis@nottingham.ac.uk

1 Laboratory for Urban Complexity and Sustainability, University of Nottingham, Nottingham NG7 2RD, UK

2 School of Physics and Astronomy, University of Nottingham, Nottingham NG7 2RD, UK

3 School of Architecture, University of Sheffield, Sheffield S10 2TN, UK
2012; Schoolman et al. 2012; Boyer et al. 2016), 'dimensions' (Stirling 1999; Lehtonen 2004; Carter and Moir 2012; Mori and Christodoulou 2012), 'components' (Du Pisani 2006; Zijp et al. 2015), 'stool legs' (Dawe and Ryan 2003; Vos 2007), 'aspects' (Goodland 1995; Lozano 2008; Tanguay et al. 2010), 'perspectives' (Brown et al. 1987; Arushanyan et al. 2017), etc. encompassing economic, social, and environmental (or ecological) factors or 'goals'. It should be noted here that these competing terms are primarily used interchangeably, and our preference for 'pillars' is largely arbitrary. This tripartite description is often, but not always, presented in the form of three intersecting circles of society, environment, and economy, with sustainability being placed at the intersection, as shown in Fig. 1. This graphic is found in various forms as a descriptor of 'sustainability' within academic literature, policy documentation, business literature, and online, and whilst often described as a 'Venn diagram', it commonly lacks the strict logical properties associated with such a construction. Alternative manifestations include the three depicted visually as nested concentric circles or literal 'pillars', or independent of visual aids as distinct categories for sustainability goals or indicators. Whilst attractive for their simplicity, the meaning conveyed by these diagrams 


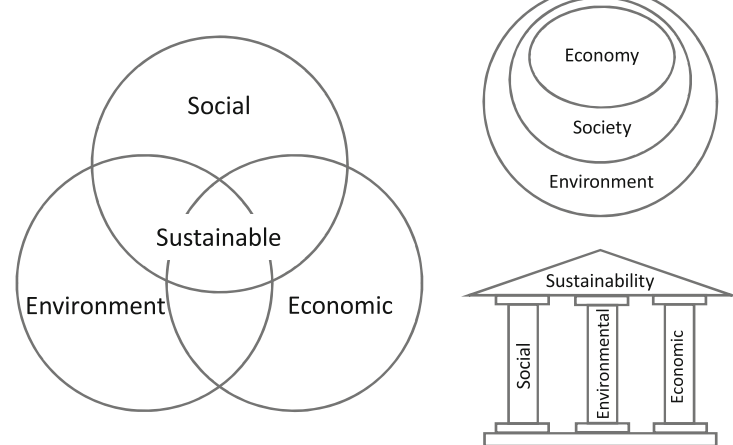

Fig. 1 Left, typical representation of sustainability as three intersecting circles. Right, alternative depictions: literal 'pillars' and a concentric circles approach

and the wider 'pillar' conception itself is often unclear, hampering its ability to be coherently operationalised. If we are prepared to overlook the lack of semantic clarity and confusion of competing terms, it can be argued that the 'three-pillar' conception of 'sustainability' (or 'sustainable development ${ }^{1}$ ) is a dominant interpretation within the literature. Yet the conceptual origins of this description, and the point at which it emerged into the mainstream, are far from clear, and its exact meaning is a matter of contention. As Thompson puts it, "much of the...discourse around sustainability...is organized around...the three-circle rubric without much disciplined thought about how it does and does not translate into a more comprehensive understanding of sustainability" (Thompson 2017).

Whilst much contemporary sustainability literature may centre around the UN's more diverse set of sustainable development goals (SDGs), the three pillars themselves were explicitly embedded in their formulation (UN 2012a). This paper aims to shed light on the origins of the 'three pillars', taking the structure of an initial review of the historical emergence of the concept of 'sustainability' from its disparate early roots to the genesis of 'sustainable development' in the 1970s and 1980s. This is followed by a literature survey tracking the early development of these concepts with an aim to probe the origins of the three pillars, prior to 2001, when the three circles diagram is first described as a 'common view' (Giddings et al. 2002). In the final discussion, we argue that the emergence of the three-pillar paradigm, with little theoretical foundation, is primarily the product of the specific origins of 'sustainability' as a concept, aided in part by the agenda of the various actors that helped to shape its early history.

\footnotetext{
${ }^{1}$ Whilst there exists an obvious semantic difference, and implicit focus in meaning, this distinction is not always present in the literature, especially in reference to the pillars formulation (Pope et al. 2004; Johnston et al. 2007; Waas et al. 2011; Carter and Moir 2012). We revisit this distinction in Sect. 4.
}

\section{Historical origins of 'sustainability'}

To understand the emergence of 'sustainability' into the mainstream in the 1980s, it is important to examine the broad roots from which the concept emerged. This is confounded by the fact that much of the work whose concepts feed into the narrative predate the language of 'sustainability'.

Authors such as Grober, Caradonna, and Du Pisani have contributed much to shedding light on a wide range of early roots (Du Pisani 2006; Grober 2012; Caradonna 2014). Of particular note are the forestry experts of the 17th and 18th centuries such as Evelyn, and Carlowitz, who introduced the concept of sustainable yield in response to dwindling forest resources across Europe (Warde 2011; Grober 2012). Of relevance too are the early political economists such as Smith, Mill, Ricardo, and Malthus who, in the shadow of the industrial revolution, questioned the limits of both economic and demographic growth, and recognised the inherent trade-offs between wealth generation and social justice (Lumley and Armstrong 2004; Caradonna 2014). The natural scientists and ecologists of the 19th century and early 20th century too help precipitate the schism between the anthropocentric conservationists on one hand, prescribing conservation of natural resources for sustainable consumption, and the biocentric preservationists, who call for preservation of nature due to its inherent worth (Callicott and Mumford 1997).

The modern concept, along with the language of sustainability in a global sense did not emerge, however, until the late 20th century. The Club of Rome's 'Limits to Growth' argues for a "world system ... that is sustainable" (Meadows et al. 1972); this, claims Grober (2012, p155), marks the first modern appearance of the term in its broad global context. The same year, in 'A Blueprint for Survival', which draws on the unpublished manuscript for 'Limits to Growth', the editors of The Ecologist present their proposals for the creation of a 'sustainable society' (The Ecologist 1972). Whatever the exact origins of the language, it is from the early 1970s that the concept snowballs; the World Council of Churches' commission on 'The Future of Man and Society' in 1974 deem the notion of a 'sustainable society' more palatable than the language of limits (Grober 2012, p167). The Ecology Party (later to become the British Green Party) adopted their 'Manifesto for a Sustainable Society' in 1975 (The Ecology Party 1975), and a series of books were published prominently featuring the language of sustainability (Stivers 1976; Meadows 1977; Pirages 1977; Cleveland 1979; Coomer 1979).

In the interests of brevity, we leave much of the earlier discussion to authors already mentioned. Instead we pick 
up the narrative at the cusp of the 1960s environmental movements, choosing to focus on the strand of 'development' and how its critique contributed to the rise of 'sustainable development' in the 1980s.

\section{A twin critique of 'economic development'}

Soon after the Second World War, there emerged a consensus in the Western world that there was an urgent need for international efforts to aid the 'development' of 'less advanced countries' (Arndt 1987, p49). It was during this time that the notion of 'economic development', outside of Marxist discourse, evolved from specifically denoting the exploitation of natural resources in a colonial context, to refer to a rise in material well-being indicated by an increase in the flow of goods and services, and growth in per capita income (Arndt 1981). Thus from the 1950s, 'economic development' became almost synonymous with 'economic growth', which in turn had become a major goal of Western economic policy, although the application of the former term was primarily reserved for poorer countries (Arndt 1987, p51). Truman's 1949 'Point Four' marked the first large-scale technical assistance development programme, notions of building up capital followed, and by 1961 the United Nations declared "International Trade as the primary instrument for economic development" (ibid. p72).

The late 1960s and early 1970s witnessed the rise of the modern environmental movement in the West (Rome 2003; Du Pisani 2006; Tulloch 2013). Popular publications such as Carson's 'Silent Spring' (1962), Ehrlich's 'The Population Bomb' (1968), and The Ecologist's 'A Blueprint for Survival' (1972), coupled with widespread media coverage of environmental disasters, such as the Santa Barbra oil spill (1969), acted to increase awareness of the magnitude of the widespread environmental destruction caused by humans. It has also been argued that the environment and quality of life issues came to the fore in the West at this point because 'basic economic needs' had been met following the economic growth of the post-war period (Dunlap and Mertig 1991; Martínez-Alier 1995).

The questioning of economic growth began to reemerge, with the prominent works of 'Limits to Growth' (1972) and Schumacher's 'Small is Beautiful' (1973) both arguing that the modern growth-based economy was unsustainable on a finite planet. The 1973 Oil Crisis, however, and the worldwide recession that followed, helped to crystallise the idea of the limitations of growth into both the mainstream and the academic discourse (Du Pisani 2006). This early discourse was radical and argued that the capitalist economic growth of the Western world was fundamentally incompatible with ecological and social sustainability and called for structural reform (Van Der Heijden 1999; Tulloch 2013; Tulloch and Neilson 2014).

Coupled with an environmental critique of the economic growth paradigm in the West was a broad criticism of economic development programmes being implemented in the developing world for their lack of environmental considerations. Caldwell details several of numerous cases of failed development projects presented at the 1968 Airlie House Conference on Ecological Aspects of International Development (Caldwell 1984). The recurring theme of these projects was a tendency to prioritise short-term gains over serious considerations of ecological impacts, either to biodiversity or ecosystem services. This forms part of a broader critique of the seeming hubristic belief inherent in the mainstream development discourse of man's ability to dominate and control natural ecological processes (Woodhouse 1972).

At the same time it was becoming apparent to many that the 'progress' that had been promised by the early economic growth-based development programmes was in many ways failing to materialise. Whilst the post-war economic boom had seen a broad rise in living standards in the West, the focus began to shift to the gross inequalities and poverties that still existed in many of these societies (Hicks and Streeten 1979). This led to a second prominent counter-discourse in the development literature, critiquing the focus on economic growth, with calls for a shift from a focus of means to ends, to better consider social problems, and a 'basic needs' approach. Arndt suggests that the first prominent example of this was Seers' 'The Meaning of Development' (1969), which argued that economic growth not only failed as a solution to social difficulties, but often was the cause of them. Seers argued that indicators of poverty, unemployment, and inequality provided a truer depiction of the state of 'development' or 'progress' (Seers 1969; Arndt 1987, p91). Notable too is Hirsch's 'Social Limits to Growth' (1976), which probes the pursuit of growth and its fetishisation at the societal level, arguing that it acts to perpetuate inequalities, and that in fact the social limits to e.g. productivity gains are more prescient than distant physical limits (Hirsch 1995). This broad social critique of growth-focused development received attention from both the International Labour Office (ILO) and the World Bank (see e.g. Hicks and Streeten 1979; ILO 1976; Streeten and Burki 1978), to the extent that it was considered by some to be the "current consensus" (Arndt 1987, p92).

The 1972 UN Conference on the Human-Environment in Stockholm marked the first global summit to consider human impacts on the environment, and the first major attempt to reconcile economic development with environmental integrity which were commonly regarded as incompatible (Caldwell 1984). Emergent from the 
conference was the concept of 'environmentally sound development', which by 1973 had been coined as 'ecodevelopment' (Clinton 1977; Mebratu 1998). 'Eco-development' was defined by Ignacy Sachs in 1978 as "an approach to development aimed at harmonising social and economic objectives with ecologically sound management, in a spirit of solidarity with future generations", further calling for "another kind of qualitative growth" (Glaeser 1984, p25). Credited as one of the earliest ecological economists, Sachs, as an adviser to the United Nations Environmental Program (UNEP), was influential in promoting this growth-sceptic concept in policy circles during the 1970s (Gómez-Baggethun and Naredo 2015; MartinezAlier 2015).

The core elements of 'eco-development' are described as the meeting of 'essential human needs', participation, environmental considerations, and the unifying principle of 'self-reliance', understood as not just freedom from the structural dependence on other nations, but freedom for the individual from the pressures of political powers or transnational corporations (Glaeser 1984, pp25-28). Important was the discussion of both local and international power structures and how eco-development faced an uphill battle in challenging them. In this body of literature, economic growth plays something of a neutral role. Sachs downplays the notion of 'trade-offs' between environmental management and economic growth, instead arguing for "a different, environmentally prudent, sustainable, and socially responsible growth", bearing remarkable similarities with later United Nations rhetoric (Glaeser 1984, p216; Berr 2015). This approach seems to differ from that of other early ecological economists such as Daly and Mishan who suggested no-growth, and slow-growth economies (Daly 1973; Mishan 1977).

Whilst the environment was being reconciled with economic development, the 'basic needs' approach was being rejected by governments in the developing world; following the global economic slump of the late 1970s, there arose a tendency to see the aspirations of 'modernisation', and the creation of a 'new international economic order', as more important than, and incompatible with, a basic needs approach (Arndt 1987, pp104-111). Coupled with this, Sachs claims the basic needs-focused 'eco-development' was vetoed as a term in international policy forms by the US administration (Gómez-Baggethun and Naredo 2015). With social critique somewhat pushed aside, McNamara, President of the World Bank, called for the need to "recapture the momentum of economic growth" (Arndt 1987).

By the 1980s, the early environmental movements had lost momentum, as the wave of the radical social movements broke and rolled back (Van Der Heijden 1999). Having been somewhat subdued, throughout the 1980s, the twin ecological and social critiques of economic development began to interweave with economic development under what was to be termed 'sustainable development' (O'Riordan 1985; Barbier 1987; Brown et al. 1987). Thus, in 1987 when the UN World Commission on Environment and Development published its report 'Our Common Future' (the Brundtland Report), calling for "a new era of economic growth-growth that is forceful and at the same time socially and environmentally sustainable", the debate had come full circle: economic growth was no longer the problem, but it was the solution (UN 1987). Co-opting the eco-development argument of a 'different quality' of economic growth, a new 'win-win' scenario emerged by recasting the same old economic growth in "socially and environmentally sustainable" colours.

\section{Assimilation into the mainstream: the institutionalising of 'sustainable development'}

Although the term had been in use for some time (e.g. IUCN, UNEP, WWF 1980), the Brundtland commission is widely credited with popularising the concept of 'sustainable development' by introducing it into international policy discourse (Basiago 1999; Castro 2004; Johnston et al. 2007; Pope et al. 2004; Redclift 2005; etc.). It defined 'sustainable development' as "development that meets the needs of the present without compromising the ability of future generations to meet their own needs". In the years following the publication of the Brundtland Report, 'sustainable development' became the dominant paradigm of the environmental movement, and the literature considering it grew exponentially.

The institutionalising of 'sustainable development' would continue with the 'Rio Process', initiated at the 1992 Earth Summit in Rio, where the world's political leaders pledged their support to the principle of sustainable development (Jordan and Voisey 1998). Central to this was the publication of the 'Rio Declaration' consisting of 27 principles intending to guide future 'sustainable development', and 'Agenda 21' which articulates a plan for putting these principles into practice. Agenda 21 built upon the Brundtland Report, emphasising the problems of the North-South development divide, championing economic growth and free trade, and emphasised the need to link social and economic development with environmental protection (UN 1992). Subsequent summits occurred in 1997, 2002, and 2012.

Despite the importance of global efforts such as the Rio Declaration and Brundtland Report in bringing 'sustainability' into the mainstream policy discourse, the consensus building through compromise approach taken has been criticised. Tulloch argues these documents were 
responsible for transforming what was a "marginal counter-hegemonic radical movement" into a platform for legitimising and obscuring globalised neoliberal policy (Tulloch 2013). Indeed, the approach taken by the UN follows the assumptions that poverty causes environmental degradation; this environmental degradation can be reduced by reducing poverty; to reduce poverty, developing countries need economic growth, which requires freer markets (Castro 2004). This logic is at best simplistic (Lélé 1991), and at worst smuggling an inherently ideological agenda under the guise of benign necessity (Tulloch 2013), clearly running in direct opposition to the earlier growthcritical works. Indeed Dryzek, in his categorisation of environmental discourses, describes sustainability as 'reformist', in opposition to the 'radical' discourses advocating systemic change, such as the limits discourse (Dryzek 2005, pp13-16).

Criticism of the almost 'business-as-usual' approach of 'sustainable development', which has been promoted to the mainstream by bodies such as the UN, has led to a heterogeneous counter-discourse. A common critique is of the 'sufficiently vague' (Daly 1996) definition promoted by the international mainstream, ambiguous enough to allow for consensus building, but devoid of much substance. By the mid-1990s, the concept of 'sustainable development' and the notion of 'sustainability' were in vogue (Gatto 1995), finding their way into academic literature and policy agendas around the globe.

\section{Environment, economics, and the society: three pillars of sustainability emerge?}

Despite the relative dearth of literature probing 'sustainability' and 'sustainable development' conceptually, one conceptualisation, that of 'three pillars', environmental, economic, and social, has gained widespread traction. This is typically realised as the balancing of trade-offs between seemingly equally desirable goals within these three categorisations, although uses vary. One problematic facet of this conceptualisation, however, is its lack of theoretical development; there appears to be no original urtext from which it derives, seemingly just appearing in the literature and commonly taken at face value. As early as 2001, this approach has been presented as a 'common view' of sustainable development (Giddings et al. 2002), so commonplace it seems not to require a reference.

Although the 'three pillars' have become commonplace throughout the literature, they are not universal. Some works consider additional pillars such as institutional (Spangenberg et al. 2002; Turcu 2012), cultural (Soini and Birkeland 2014), and technical (Hill and Bowen 1997). Other frameworks bypass the compartmentalisation of sustainability completely. Milbrath for example presents a vision of a 'sustainable society' based on a set of defined values (Milbrath 1989), the 'Natural Step' framework is based upon four guiding criteria (Upham 2000), and Giddings et al.'s conceptualisation involves principles of equity (Giddings et al. 2002). More recently too, the SDGs developed by the UN have evolved an 'integrated' approach adopting 17 broad goals over a smaller number of categorisations.

The origins of the 'three-pillar' paradigm have been variously attributed to the Brundtland Report, Agenda 21, and the 2002 World Summit on Sustainable Development (Moldan et al. 2012), yet in none of these documents is a clear framework or theoretical background made explicit. In what follows, in an attempt to uncover the origins of the 'three pillars', we analyse the documents of the International Union for Conservation of Nature (IUCN), which present the first widely cited conceptualisation of 'sustainable development' (Pezzey 1992; Sneddon 2000), and those of the United Nations, whose 1987 report is widely credited with bringing sustainable development to the mainstream. We then turn to the academic literature of the 1980s and 1990s which considers sustainability conceptually, prior to its 2001 description as a 'common view'.

\section{The IUCN}

The first prominent occurrence of the phrase 'sustainable development' in published literature appeared in 1980 when the IUCN, in collaboration with the UNEP and the World Wildlife Fund (WWF), published their 'World Conservation Strategy', subtitled 'Living Resource Conservation for Sustainable Development' (IUCN, UNEP, WWF 1980). This early conception of sustainable development is motivated by the need for economic development, with its social and economic objectives, to take conservation into account by considering resource limitations and ecosystem carrying capacity. Whilst there is no explicit mention of the three pillars, their roots can clearly be seen, and sustainable development is briefly defined as that which "must take account of social and ecological factors, as well as economic ones" (ibid. pI). It should be emphasised that these three aspects are not held up as a framework and no judgement is made upon them. The implication appears to be that the current development policy primarily focuses on economic objectives, when it is imperative to integrate conservation objectives into policy. There is no discussion of 'trade-offs', or the relative importance of the three objectives.

The IUCN Conference on Conservation and Development in Ottawa 1986 was convened to evaluate progress in implementing the World Conservation Strategy. It concluded with a definition: "The emerging paradigm of 
sustainable development... seeks ... to respond to five broad requirements: integration of conservation and development; satisfaction of basic human needs; achievement of equity \& social justice; provision for social selfdetermination and cultural diversity; and maintenance of ecological integrity" (Jacobs et al. 1987). These requirements cohere well with social and environmental aspects, but there is nothing to suggest a predecessor of anything approaching an economic pillar.

This appears to be a consistent narrative throughout the work of the IUCN. The successor to the World Conservation Strategy, 'Caring for the Earth', calls for development that is "both people-centered ... and conservationbased" (IUCN, UNEP, WWF 1991). The strategy is based upon nine "interrelated and mutually supporting" principles of a "sustainable society", including changing attitudes, conservation of Earth's vitality and diversity, and a global alliance for attaining sustainability (ibid. pp8-12), and indicators for sustainability are presented under just two themes, "quality of life", and "ecological sustainability" (ibid. p198). In 1996, an "increased emphasis given to people" was seen as an emerging issue, as well as the need to expand use of "legal and economic tools for conservation" (IUCN 1997, pp43-45). At the same time, the models of sustainability being considered by the IUCN included the 'Egg of Sustainability' and the 'Barometer of Sustainability' both of which considered the dual goals of improving ecosystem wellbeing and human wellbeing as the essence of sustainability (IUCN 1996).

Apart from a short-lived consideration in the early 2000s, when intersecting circles are presented as the "conventional model of sustainable development" (IUCN 2004, pp9-11), the IUCN thus largely avoids the use of the three pillars, preferring instead a model of sustainability that focuses on the goals of improving the ecosystem and human well-being. Discussion of the economy is generally focused on mitigating the negative impacts on the planet's ecosystems of current practices and the need for a 'greener' economy.

\section{The United Nations}

The articulation of distinct social, economic, and environmental aspects of 'sustainable development' can be seen in Agenda 21 (1992) and are arguably implicit in the Brundtland Report (1987), although cultural and political/ institutional aspects are also present. Indeed, Agenda 21 mentions "economic, social and environmental dimensions" of sustainable development (8.4.1), but there is no conceptual justification or framework presented (UN 1992).

Following the 1992 Rio Summit, the UN established the Commission on Sustainable Development (CSD) for the provision of guidance and monitoring of progress in the implementation of Agenda 21 and the Rio Declaration. In 1995, a workshop involving policy makers, members of international organisations, and scientists was held with the intention of reviewing indicators of the "three principal aspects of sustainability" (environmental, social and economic) (UN 1995, p3). The conclusions were that the CSD should work towards a core set of indicators which equally emphasise the "economic, social, environmental and institutional aspects of sustainable development", with the extra inclusion of the institutional aspect being left unelaborated (ibid. p5). It has been argued that this inclusion was due to the institutional aspect being integral to addressing the problems of unsustainable development practice (Spangenberg et al. 2002).

The following year, the CSD published a testbed selection of 130 indicators, with the aim of having a "good set of indicators" by 2000 . These indicators were categorised under the four aspects presented in the 1995 workshop (UN 1996). Despite this, the CSD does not use these four dimensions universally. A 1997 report on progress achieved since Rio is structured on the basis of three "mutually reinforcing components" of sustainable development, "economic growth, social development and environmental sustainability" with the aim of achieving "balanced achievement of sustained economic development, improved social equity and environmental sustainability" (UN 1997, pp4-5), but with no discussion of the tensions between these objectives. The existence of "three components-economic and social development and environmental protection" is again emphasised in the sixth session report of the CSD (UN 1998, p3).

In 2001 the CSD published the second edition of their indicator framework which maintains the categorisation of economic, social, institutional and environmental 'dimensions' of sustainable development (UN 2001a). The goals of "advancement of social and institutional development, to maintain ecological integrity, and to ensure economic prosperity" are also mentioned (ibid. p21). By the third edition, however, the four dimensions were no longer elaborated explicitly to emphasise the "multi-dimensional nature" of sustainable development (UN 2007).

In parallel to the work of the CSD, the UN launched 8 millennium development goals (MDGs), to be achieved by the global community by 2015 (UN 2001b). Interestingly, Goal 7 was to "ensure environmental sustainability", although the concepts of social or economic sustainability are not explicitly explored. The report of the 2002 Earth Summit prescribes the need to "promote the integration of the three components of sustainable development-economic development, social development and environmental protection - as interdependent and mutually reinforcing pillars" (UN 2002, p8). The need for "integration" of these 
pillars, and a "balanced and holistic approach" is emphasised (ibid. p128).

The narrative of "integrating economic, social and environmental aspects" of sustainable development continues throughout the report of the next World Summit 10 years later (UN 2012b). Following the 2012 summit, an 'Open Working Group' was established to develop the SDGs for the UN's 'post-2015 process', with part of the brief being to "incorporate in a balanced way all three dimensions of sustainable development and their linkages" (ibid. p47). Indeed, when the General Assembly adopted the finalised SDGs in 2015, it is stated how the goals are "integrated and indivisible and balance the three dimensions of sustainable development: the economic, social and environmental" (UN 2015, p1). However, these three dimensions do not explicitly form any part of the framework of the 17 goals.

\section{The academic literature}

Whilst the IUCN introduced the term 'sustainable development' into the mainstream in 1980, it received little conceptualisation in the academic literature prior to the 1987 publication of the Brundtland Report. Within this period, there existed notably Caldwell's consideration of the history of 'ecologically sustainable development' as the "uneasy union" of ecological and economic values; in the absence of three explicit pillars, the need for holistic thinking was emphasised, as well as "social, legal, religious, and demographic" factors (Caldwell 1984). O'Riordan too proposes "two main kinds of sustainable utilization: ecological and sociocultural [later 'socioeconomic']" (O'Riordan 1985, p1443).

In 1987, Brown et al. identified three "perspectives, or contexts, in which the term [sustainability] is used" emerging from their review of the literature (Brown et al. 1987). The 'social' perspective concerns itself with the "continued satisfaction of basic human needs" of individuals, the 'ecological' focuses on the "continued productivity and functioning of ecosystems" as well as the "protection of genetic resources and the conservation of biological diversity", and the "elusive" 'economic' definition entails resolving "the limitations that a sustainable society must place on economic growth" (pp716-717). To Brown et al., these are different perspectives on the same concept which have emerged from the literature, closer to observation than anything approaching a conceptual framework.

The same year, Barbier articulates the development process as "an interaction among three systems: the biological (and other resource) system, the economic system, and the social system", presenting an early antecedent of the intersecting circles diagram (Barbier 1987). Each system is ascribed goals: "genetic diversity, resilience, biological productivity"; "satisfying basic needs (reducing poverty), equity-enhancing, increasing useful goods and services"; and "cultural diversity, institutional sustainability, social justice, participation", respectively. The objective of sustainable development then is to "maximise the goals across all these systems through an adaptive process of trade-offs" (p104). This work marks what seems to be the first explicit conceptualisation of the pillars, complete with diagram, and discussion of inherent 'tradeoffs'. Indeed, it is claimed that Barbier first presented this as a result of a 1986 meeting within the IIED, where he was working as an economist, proposing a more analytical approach to understanding sustainable development (Holmberg 1992, p23). Barbier too identifies himself as the progenitor of the 'Venn diagram' in a later work (Barbier and Burgess 2017), at one point referring to it as "infamous" (Barbier 2011).

Cocklin draws on Barbier, conceptualising 'sustainability' in terms of a set of goals relating to social, economic, and environmental subsystems. The relation of sustainability to other management goals such as resilience and economic efficiency is considered to be ultimately ideological in nature, and thus trade-offs occur both internally and externally (Cocklin 1989).

Dixon and Fallon differentiate between purely 'biological/physical', and 'socioeconomic' definitions of sustainability which revolve around "social and economic wellbeing", hinting at necessary structural changes to current economic activity (Dixon and Fallon 1989). Lélé distinguishes between two competing understandings of sustainable development: sustained growth, which he deems a contradiction; and ecologically sound development with implicit social objectives (Lélé 1991). Lélé holds that the concept of sustainable development requires strong clarification, arguing for the need to reject attempts to focus on economic growth and to recognise the inadequacies of neoclassical economics.

Hancock (1993) approaches a three-pillar model in efforts to consider issues of 'health' alongside sustainable communities (Hancock 1993). Hancock argues for a shift in focus from economic development to a "system of economic activity that enhances human development while being environmentally and socially sustainable" (p43). A 'Venn diagram' model is presented of health, or 'human development', being the confluence of three systems which meet several requirements: a 'community' which is 'convivial', an 'environment' which is 'viable', and 'livable' with respect to the community, and an economy which is 'adequately prosperous', 'equitable' with respect to the community, and 'sustainable' with respect to the environment. Superficially, this model is remarkably similar to contemporary models of the three pillars, but it presents the 
economy as 'subservient' to the community and environment, rather than as an entity with which trade-offs must be made.

Munasinghe claims 'sustainable development' encompasses "three major points of view: economic, social, and ecological", whereby progress is best made via integration of their competing "non-comparable" objectives. Further, three differing approaches to 'sustainability' or 'sustainable development' are articulated: the economic which maximises income whilst maintaining capital stock, the ecological which seeks to preserve biological and physical systems, and the sociocultural which encompasses equity and participation (Munasinghe 1993).

Yunlong and Smit develop Brown et al's three general definitions in reference to 'sustainable agriculture'. They stress the need for integration, but do not elaborate on how this might be achieved (Yunlong and Smit 1994). Altieri presents a version of the 'Venn diagram' in his discussion of sustainable agriculture; here, specific economic, social, and environmental goals are detailed, with the confluence representing 'agroecology' (Altieri 1995, p376). It has been suggested by Thompson (2017) that Altieri draws on Douglass (1984) in his articulation of these three domains; however, it should be noted that this diagram is absent in the first edition of Altieri's book (Altieri 1987). Derived from a 1982 conference on "Agricultural Sustainability in a Changing World Order", Douglass divides his contributors' perspectives along "economic, biological, and cultural" lines of thinking, later reiterated with the subtitles "Food Sufficiency: Resources, Technology, and Economics", "Stewardship: Biology, Ecology, and Population", and "Community: Justice, Participation, and Development". Despite the focus on agriculture, these categorisations bear many similarities with perspectives drawn in the wider sustainability literature; however like Brown et al., these are separate perspectives as observed in the literature rather than having theoretical basis. Altieri's work is placed here within the 'stewardship' camp, yet his concluding chapter emphasises the inherent linkages between the biological and socioeconomic problems of agricultural systems. He concludes, "The requirements to develop sustainable agriculture clearly are not just biological or technical, but also social, economic, and political, and illustrate the requirements needed to create a sustainable society" (Altieri 1987, p199; 1995, p379).

Basiago describes sustainability as a "methodology designed to maximize the vitality of social and environmental systems" (Basiago 1995, p119). Economic methods of defining sustainability are described (along with biological, sociological, planning, and ethical methods), although Basiago argues that "a major restructuring of the economy is implied by economic methods".
The work of Goodland and Daly (Goodland 1995; Goodland and Daly 1996) seeks to distinguish the concept of 'environmental sustainability' from social and economic sustainability. They take a largely systems-based approach to the environmental pillar, defining it in terms of inputoutput laws. They are critical of what they perceive as the term 'sustainability' becoming a "landfill dump for everyone's environmental and social wishlists" (Goodland and Daly 1996, p1002). Contrasting to a holistic integrated approach, they argue that the three 'types' of sustainability are "clearest when kept separate", and that "the disciplines best able to analyse each type of sustainability are different" (ibid.).

In contrast, Milne suggests that it is "generally accepted that 'sustainability' is about integrating social, economic, and ecological values" ( $p 137$ ), but cautions a lack of agreement in interpretation, distinguishing between authors who call for 'balancing', and those who prioritise the biological aspect (Milne 1996). Milne leans towards the latter, concluding that "sustainability requires the subordination of traditional economic criteria to criteria based on social and ecological values". The World Resources Institute, attempting to produce environmental indicators for 'sustainable development' argue that "sustainability involves-at a minimum-interacting economic, social, and environmental factors" arguing that inadequate attention has been given to the latter (pp2-3). They too argue that sustainable development is that which attempts to "reconcile or establish a balance" (p31) between these factors (Hammond et al. 1995).

Macnaghten and Jacobs (1997) argue that the 'general model' of sustainable development, which emerges from the literature, emphasises trade-offs between economic growth, deteriorating environmental conditions, and a decline in the quality of life (Macnaghten and Jacobs 1997). The authors argue for a model whereby 'economic welfare' is a component of the quality of life, which in turn is ultimately constrained by 'environmental limits'. Such a nested model, as presented to the right of Fig. 1, has been viewed as preferable to a 'Venn diagram' of trade-offs by numerous authors for its emphasis that the three systems represented by the pillars cannot be separated and are in fact subsystems of each other (Mebratu 1998; Giddings et al. 2002). Striking similarities can be seen between this nested model and a much earlier one by Renè Passet, a contemporary of Ignacy Sachs (Passet 1979). Passet's systems approach emphasises that the sphere of economy is situated within the sphere of human activities, where social welfare is not reduced to the mere accumulation of goods and services, which in turn is situated within the biosphere (pp9-12). The diffusion of this model into the sustainability literature is uncertain; Passet's work was likely familiar to Sachs, yet the model appeared to receive little 
attention as a primary source in the English language until much later.

Custance and Hillier (1998) detail their work in developing a set of sustainable development indicators for the UK government (Custance and Hillier 1998). Here, sustainable development is again understood as the "balance between three broad objectives-maintenance of economic growth, protection of the environment ... and social progress". They build upon a set of indicators developed in 1996 which focused primarily on the economic-environmental interaction, acknowledge the importance of including a social dimension, but question whose role it is to define sustainable development. This work reflects a broader body of literature considering 'indicators' of sustainable development utilising the three pillars which appears to arise around this time (Bradley Guy and Kibert 1998; Fricker 1998; Stirling 1999; Azapagic and Perdan 2000; Valentin and Spangenberg 2000).

Parallels to the three pillars can be seen in Campbell's 'planning triangle'. Campbell produced a model of what he perceived as three major goals or priorities of urban planning: social justice, economic growth, and environmental protection (Campbell 1996). Campbell argues that these goals introduce three fundamental conflicts, yet at the elusive centre of the three lies 'sustainable development', the balance of these goals. Campbell acknowledges the difficulty of finding this balance, emphasises the need to think holistically and move towards shared language, and urges collaboration between development planners and environmental planners. Campbell's discussion explicitly highlights the notion of conflict or competition between these goals and of the need for interdisciplinary approaches in elaborating upon them towards a more comprehensive and rigorous conceptual framework.

Of final note is the treatment of sustainability within the business literature. From the late 1990s, Elkington's 'triple bottom line' (TBL) accounting method gained traction with the publication of his popular book 'Cannibals With Forks' (Elkington 1997). Drawing strong parallels with three pillars, the traditional financial 'bottom line' of a corporation is complimented by bottom lines for social and environmental performance, termed 'people, planet, profit', encouraging firms to consider longer-term perspectives in their decision making. Corporate usage of the TBL has been met with scepticism in academic circles, however, with little evidence of effective use among the bodies that claim to advocate it. It has been argued that the TBL jargon is inherently empty, vague, and misleading (Norman and Macdonald 2004), paradoxically perpetuating business-asusual approaches (Milne and Gray 2013). Whilst 'corporate sustainability' may trace its roots to 'corporate social responsibility' which arose in the $1950 \mathrm{~s}$, it was not until the 1990s that larger companies started publishing reports emphasising environmental issues, and later certain health issues, although the language of sustainability was rarely used (Milne and Gray 2013). Numerous 'sustainability accounting' methods predate the TBL, yet Elkington's work appears to mark the first use of a three-pillar conceptualisation here (Lamberton 2005). Whilst this body of literature does not appear to be the origin of the three-pillar framework, it seems that the TBL, which is presented in many cases as synonymous with sustainability, may have been influential in cementing its position in the mainstream into the 21 st century.

\section{Discussion}

Having reviewed much of the early literature, with the motivation of probing the genesis of the 'three-pillar' paradigm, it is of some concern to find no clear answers. Whilst the work of Barbier (1987) appears to provide the origin of the widespread circles diagram and provides a framework to encourage maximisation of the goals of three systems, subject to implied trade-offs, it differs from later uses, most notably in its treatment of the economic system. The 'three-pillar' formulation itself, however, predates Barbier, at least implicitly, appearing in the IUCN's 1980 'World Conservation Strategy', O'Riordan (1985), the contemporaneous Brown et al. (1987), as well as in works preceding the language of sustainability, such as the discussions of 'eco-development' by Sachs and Passet's 1979 work.

Of the various works discussed here, it is possible to broadly distinguish between two ways in which the pillars have been conceptualised. The first approach follows that of Barbier in presenting the individual dimensions as distinct, yet interacting systems, as taken by e.g. Cocklin (1989), Hancock (1993), and Basiago (1995). Secondly, there are those who follow from Brown et al. in seeing three distinct, yet interrelated perspectives or schools of thought such as Lélé (1991), Munasinghe (1993), and Goodland and Daly (1996).

\section{Competing realities}

The systems approach had been used earlier by Passet, who may have indirectly contributed to its use. This approach typically presents three distinct systems with their own 'goals', and the interactions of these systems must be managed to meet these goals and the emergent goal of sustainability or sustainable development. The clearest example of this is given by Barbier (1987) and Cocklin (1989) who both emphasise integration of the systems and management of trade-offs between them. Hancock (1993) and Basiago (1995) also take a systems approach, but the 
implication is that the individual systems strengthen and enhance each other. Campbell (1996) also emphasises reconciliation. Here, we would place the approaches taken by the UN and IUCN who, whilst generally avoiding the language of systems, talk about these individual dimensions having specific goals. In a similar vein then too, Munasinghe (1993), Altieri (1995), Milne (1996), and Custance and Hillier (1998) all discuss the integration and balancing of goals, whereas Macnaghten and Jacobs (1997) use the language of trade-offs. The language involved here frequently invokes the need to "integrate", "balance", and "reconcile" the pillars without necessarily articulating what this means in practice; whether this requires uncomfortable 'trade-offs' or not appears to depend on the level of optimism the work in question is pitching for. This missing link between theory and application is problematised by Barbier and others in a later work (Barbier and Markandya 2013, p38; Barbier and Burgess 2017); it is difficult to make decisions about trade-offs without knowing the implications of such choices and, whilst they offer a utility maximisation approach, it remains value laden. There thus appears an uncomfortable gap between undertheorisation, on the one hand and making necessary political value judgements to allow for application, on the other.

Alternative to a systems interpretation are the authors who talk about the three pillars as distinct perspectives of sustainability. These discussions range from calls for clarity of competing definitions: Brown et al. (1987), Dixon and Fallon (1989), Lélé (1991); further undertheorised calls for integration of these perspectives: Douglass (1984), Yunlong and Smit (1994); and Goodland and Daly (1996)'s argument to retain disciplinary distinctions: "social scientists are best able to define social sustainability" (p1002). Blurring the lines of systems/perspectives distinctions come later descriptions such as the '3Ps' of Elkington, or the '3Es' (environment, economy, equity) (Caradonna 2014), which embody broad values further removed from explicit conceptualisation.

Further to these distinctions, the meaning of the economic pillar remains a central point from which much of the early literature diverges. A prominent strand is heavily critical of the dominant global economic paradigm and sees the economic pillar as a means of producing systemic change, both by erring away from the growth narrative and thinking of the 'economy' as subordinate to social wellbeing and environmental health. This can be seen in Brown et al.'s (1987) considerations of placing limitations on growth, Basiago's call for economic 'restructuring', and Milne's call for "subordination of traditional economic criteria". Barbier and Altieri both reject economic growth as their economic goals, and the IUCN too remains wary of the economic system throughout their literature, instead focusing on the balancing of environmental and social goals.

This contrasts heavily with the understanding pushed by the UN, where growth is imperative. Rather than being met with scepticism, a growth-focused economic pillar is central to their sustainable development narrative; here, growth is key to meeting the social and environmental goals through trickle-down effects. The presentation of an economic pillar centred on growth, equal in importance to social and environmental pillars of sustainability, as an unquestioned, unprobed necessity cements this framing of the pillars as common sense. A lack of a clear conceptual basis acts further to hide this framing from critique, allowing for broad consensus from institutional actors that would otherwise have conflicting priorities. This highlights the problems of undertheorised calls for 'integration' and 'balancing' of the pillars without the acknowledgement that any attempt to do so in practice is value driven.

\section{Historical emergence?}

It can be argued that many of the conflicting conceptualisations of the three pillars, and sustainability itself, can be attributed to the historical origins of this body of literature. As has been suggested above, the historical roots and emergence of 'sustainability' is far from a straightforward narrative; indeed, Kidd identifies six distinct but related strains of thought feeding in (Kidd 1992), and there are arguably more. It is here that we can begin to see the origins of why the sustainability literature is so broad and confusing; as Kidd argues, it is deeply embedded in fundamentally different concepts. From the development specialists to the ecological economists, and systems ecologists, various broadly distinct schools co-opt the language of 'sustainability' around the same time, leading to what has become such a heterogeneous discourse. As Dryzek has argued, we then see a wide range of actors who see the emergence of 'sustainability' as a dominant discourse and recognise it as ripe for shaping in terms that are favourable to them (Dryzek 2005, p146). What arguably unites these disparate roots is criticism of the economic status quo, be that realised by blind pursuit of economic growth, short-sighted profit-driven agriculture, or industrialism with little regard to the fragility of complex ecosystems.

Thus, focusing on the economic development strand as explored previously, we argue that 'sustainable development' arose here from a twin critique of the previously popular notion of 'economic development', from both a 'quality of life' or social perspective, and an ecological perspective. Caldwell goes into some depth discussing the ecological critique, arguing that the 1972 Stockholm Conference succeeded in placing the need to reconcile 
economic development and environmental protection on the global agenda, and precipitated the notion of 'eco-development' (Caldwell 1984). The early social critique is explored by Arndt (1987) and is picked up by the Brundtland Report which holds that poverty and environmental problems are inherently linked, and that "meeting essential needs" is a key requirement of development (UN 1987, p16).

Thus, we see the three pillars are fundamentally rooted here in 'sustainable development' from its conception. Further, we argue that this narrative of environmental and social critiques of the economic status quo is replayed over various other strands that adopt the language of sustainability. This can be seen in the work of the IUCN, which approaches 'sustainable development' from the concept of conservation, in the limits discourse, considerations of sustainable agriculture as articulated by Douglass, as well as in Elkington's TBL. We now begin to see why the economic pillar is so fundamental-what unites these disparate discourses is the perceived inadequacy of the 'economic', be it from environmental or social perspectives. The confusion of competing conceptualisations and different interpretations of the economic pillar within this early literature can then be understood if we view sustainability not as a coherent singular concept, but as a common language of broad schools of thought with the commonality of this 'economic' critique.

The depiction of the economic pillar in terms of an economic growth goal, placed on equal footing with social and environmental factors, despite the wealth of critical literature, can be seen as an embodiment of the ideological win-win scenario of 'sustainable growth' pushed in the 1987 Brundtland Report. This was further reinforced by the 1992 Rio summit and publication Agenda 21 which brought this particular interpretation of 'sustainable development' to global attention. It has been argued by some that this neutralisation of the radical economic critique via institutionalisation was an inevitable consequence of the UN's consensus building approach to addressing 'sustainability' (Huckle 1991; Carruthers 2001).

This 'emergence' of the three-pillar model thus leads to it being in many cases presented, with little to no theoretical foundation or justification, as the norm, or a 'common sense' understanding of sustainability. This is mirrored in the documents of the UN and may be seen too within organisations such as the OECD, which, in a 2000 report on indicators, heavily emphasise the need to better understand the "complex synergies and trade-offs" between the "three dimensions" of sustainable development (OECD 2000, p19).

\section{'Sustainability' vs. 'sustainable development'}

So far, we have sidestepped focusing on the competing language of 'sustainability' and 'sustainable development', as the two are often so intertwined in the literature that they remain difficult to tease apart. It is through this conflation though that economic growth-centred 'development' becomes an implicit part of 'sustainability', skipping over the questions: Development of what? Development for whom? Such strategic ambiguity allows this fuzzy concept to be utilised by any actor for their own means. In the earlier literature such as Caldwell, and Barbier, 'sustainable development' is understood as a necessity for developing nations and is often decoupled from growth. But this distinction is lost when the UN equates development with growth, and the OECD calls for sustainable development for their member countries, i.e. developed nations (OECD 2004, p3).

This issue has been addressed by numerous authors who hold the term 'sustainable development', like that of 'sustainable growth', to be an oxymoron (Redclift 2005; Johnston et al. 2007; Brand 2012). Notably Redclift argues the notion of 'development', rooted in Western colonial capitalist narratives, presents numerous barriers to sustainability, and without interrogation and political change, sustainability itself is jeopardised (Redclift 1987). Sneddon proclaims that 'sustainable development' has "reached a conceptual dead-end", and that for clarity it is necessary to decouple the notion of 'sustainability' from its counterpart (Sneddon 2000). He problematises the recasting of 'development' as sustainable, citing the numerous socio-ecological abuses enacted throughout its history and its blindness to deep-set structural issues. 'Sustainability' on the other hand, despite having perhaps a reputation as a buzzword, carries far less historical baggage and its necessity for a specific context prompts conceptual questions, such as for whom and of what. Looking at the more contemporary literature, however, it seems little has changed and the recent articulation of the SDGs has further entrenched the notion of 'sustainable development'.

\section{Conclusions}

In seeking to clarify the origins of the notion of the 'three pillars of sustainability', we have shown that the conceptual foundations of this model are far from clear and there appears to be no singular source from which it derives. Whilst a diagram with explicit economic, social, and biological system goals is presented as a model of sustainable development by Barbier in 1987, the goals elaborated differ from those of the UN and the meaning is limited to 
developing nations. Further, an implicit notion of these three pillars predates this, appearing in work by the IUCN and in consideration of 'eco-development'.

We have argued that the early literature considering the pillars may be split broadly between those who view the three as distinct perspectives, and those who take a systems approach. Within these formulations, there lacks a commonality in how interactions are treated, whether trade-offs occur or mutual reinforcements are made. The implications of 'integration' here are often undertheorised leading to the value judgements necessary for application often slipping by unnoticed and depoliticised. This is seen most clearly as the major source of disagreement stemming from the treatment of the economic pillar.

By drawing on Kidd's argument that the discourse is fundamentally rooted in different schools of thought who have all adopted the common language of 'sustainability', we suggest that this presents itself as the source of much confusion and competing conceptualisation. Central to these distinct schools, however, can be seen a broad critique of the economic status quo, both from ecological and social perspectives. Focusing on the development literature has allowed us to present an example of twin ecological and 'basic needs' critiques of 'economic development' from the 1960s, crystallising into three pillars of 'sustainable development' in the 1980s. We have then argued that this narrative is replayed across various other schools of thought under the language of 'sustainability', such as those considering agriculture or conservation.

As these conflicts play out, 'sustainable development' is institutionalised by the UN in the 1987 Brundtland Report, and during the subsequent Rio process, which pushes an understanding placing economic growth as the solution to ecological and social problems. This 'win-win' approach reflects the biases inspired by their intergovernmental consensus building remit, and effectively neutralises much radical critique by depoliticising sustainability and presenting three sets of equally important economic, social, and environmental goals as benign necessity. This notion is further entrenched by the blurring of the language of 'sustainability' and 'sustainable development' such that economic development remained an implicit, but inadequately formulated, part of sustainability.

A consequence of the lack of rigour in the theoretical underpinnings of sustainability and the three-pillar paradigm is the difficulty in producing operational frameworks for the characterisation of sustainability which remain rooted in theory. Such applications would necessarily be context specific, requiring careful consideration of both spatial and functional boundaries. Although the targets and indicators associated with the UN SDGs are encouraging, a lack of detail is given to a transparent rigorous theoretical foundation in which to ground them and the value judgements that have been made along the way.

Despite this paper being mostly retrospective, focusing upon historical literature, it brings to light important issues that are still relevant today. There remains an urgent need to critically examine the models we employ for understanding. The inherently political nature of sustainability can often be forgotten, and we should be careful to avoid reproducing models without carefully considering their theoretical basis and the embedded ideology within them. Finally, it should be remembered that sustainability, through its complex and disparate historical origins, remains both context specific and ontologically open, and thus any rigorous operationalisation requires explicit description of how it is understood.

Acknowledgements This work was supported by the Engineering and Physical Sciences Research Council [grant number 1643433]; and the Leverhulme Trust research programme grant 'Sustaining urban habitats: an interdisciplinary approach'.

Open Access This article is distributed under the terms of the Creative Commons Attribution 4.0 International License (http://creative commons.org/licenses/by/4.0/), which permits unrestricted use, distribution, and reproduction in any medium, provided you give appropriate credit to the original author(s) and the source, provide a link to the Creative Commons license, and indicate if changes were made.

\section{References}

Altieri MA (1987) Agroecology: the scientific basis of alternative agriculture, 1st edn. Westview, Boulder

Altieri MA (1995) Agroecology: the science of sustainable agriculture, 2nd edn. Westview Press, Boulder

Arndt HW (1981) Economic development: a semantic history. Econ Dev Cult Change 29:457-466

Arndt HW (1987) Economic development: the history of an idea. University of Chicago Press, Chicago

Arushanyan Y, Ekener E, Moberg Å (2017) Sustainability assessment framework for scenarios-SAFS. Environ Impact Assess Rev 63:23-34. https://doi.org/10.1016/j.eiar.2016.11.001

Azapagic A, Perdan S (2000) Indicators of sustainable development for industry: a general framework. Trans IChemE 78:243-261. https://doi.org/10.1205/095758200530763

Barbier EB (1987) The concept of sustainable economic development. Environ Conserv 14:101. https://doi.org/10.1017/ S0376892900011449

Barbier E (2011) The policy challenges for green economy and sustainable economic development. Nat Resour Forum 35:233-245. https://doi.org/10.1111/j.1477-8947.2011.01397.x

Barbier EB, Burgess JC (2017) The sustainable development goals and the systems approach to sustainability. Econ Discuss Pap 28:1-24. https://doi.org/10.5018/economics-ejournal.ja.2017-28

Barbier EB, Markandya A (2013) A new blueprint for a green economy. Routledge, Abingdon

Basiago AD (1995) Methods of defining "sustainability". Sustain Dev 3:109-119. https://doi.org/10.1002/sd.3460030302

Basiago AD (1999) Economic, social, and environmental sustainability in development theory and urban planning practice. 
Environmentalist 19:145-161. https://doi.org/10.1023/A: 1006697118620

Berr E (2015) Sustainable development in a post Keynesian perspective: why eco-development is relevant to post Keynesian economics. J Post Keynes Econ 37:459-480. https://doi.org/10. 1080/01603477.2015.1000173

Boyer R, Peterson N, Arora P, Caldwell K (2016) Five approaches to social sustainability and an integrated way forward. Sustainability $8: 1-18$. https://doi.org/10.3390/su8090878

Bradley Guy G, Kibert CJ (1998) Developing indicators of sustainability: US experience. Build Res Inf 26:39-45. https://doi.org/ 10.1080/096132198370092

Brand U (2012) Green economy-The next oxymoron? GAIA Ecol Perspect Sci Soc 21:5

Brown BJ, Hanson ME, Liverman DM, Merideth RW (1987) Global sustainability: toward definition. Environ Manage 11:713-719. https://doi.org/10.1007/BF01867238

Caldwell LK (1984) Political aspects of ecologically sustainable development. Environ Conserv 11:299-308. https://doi.org/10. 1017/S037689290001465X

Callicott JB, Mumford K (1997) Ecological sustainability as a conservation concept. Conserv Biol 11:32-40. https://doi.org/10. 1046/j.1523-1739.1997.95468.x

Campbell S (1996) Green cities, growing cities, just cities?: Urban planning and the contradictions of sustainable development. J Am Plan Assoc 62:296-312. https://doi.org/10.1080/ 01944369608975696

Caradonna JL (2014) Sustainability: a history. Oxford University Press, Oxford

Carruthers D (2001) From opposition to orthodoxy: the remaking of sustainable development. J Third World Stud 18:93-112

Carter K, Moir S (2012) Diagrammatic representations of sustainability - a review and synthesis. In: Smith SD (ed) Proceedings of the 28th annual ARCOM conference, 3-5 September 2012. UK, Edinburgh, pp 1479-1489

Castro CJ (2004) Sustainable development: mainstream and critical perspectives. Organ Environ 17:195-225. https://doi.org/10. $1177 / 1086026604264910$

Cleveland H (1979) The management of sustainable growth. Pergamon Press, New York

Clinton RL (1977) Ecodevelopment. World Aff 140:111-126

Cocklin CR (1989) Methodological problems in evaluating sustainability. Environ Conserv 16:343-351. https://doi.org/10.1017/ S0376892900009772

Coomer JC (1979) Quest for a sustainable society. Pergamon Press, New York

Custance J, Hillier H (1998) Statistical issues in developing indicators of sustainable development. J R Stat Soc 161:281-290

Daly HE (1973) Toward a steady-state economy. W. H Freeman, New York

Daly HE (1996) Beyond growth: the economics of sustainable development. Beacon Press, Boston

Dawe NK, Ryan KL (2003) The faulty three-legged-stool of sustainable development. Conserv Biol 17:1458-1460. https:// doi.org/10.1046/j.1523-1739.2003.02471.x

Dixon JA, Fallon LA (1989) The concept of sustainability: origins, extensions, and usefulness for policy. Soc Nat Resour An Int J 2:73-84. https://doi.org/10.1080/08941928909380675

Douglass GK (1984) Agricultural sustainability in a changing world order. Westview Press, Boulder

Dryzek JS (2005) The politics of the earth: environmental discourses, 2nd edn. Oxford University Press, Oxford

Du Pisani JA (2006) Sustainable development-historical roots of the concept. Environ Sci 3:83-96. https://doi.org/10.1080/ 15693430600688831
Dunlap RE, Mertig AG (1991) The evolution of the US environmental movement from 1970 to 1990: an overview. Soc Nat Resour 4:209-218. https://doi.org/10.1080/08941929109380755

Ecologist The (1972) A blueprint for survival. Penguin, Harmondsworth

Elkington J (1997) Cannibals with forks: the triple bottom line of 21st century business. Capstone, Oxford

Fricker A (1998) Measuring up to sustainability. Futures 30:367-375. https://doi.org/10.1016/S0016-3287(98)00041-X

Gatto M (1995) Sustainability: Is it a well defined concept? Ecol Appl 5:1181-1183

Gibson RB (2006) Beyond the pillars: sustainability assessment as a framework for effective integration of social, economic and ecological considerations in significant decision-making. J Environ Assess Policy Manag 8:259-280

Giddings B, Hopwood B, O'Brien G (2002) Environment, economy and society: fitting them together into sustainable development. Sustain Dev 10:187-196. https://doi.org/10.1002/sd.199

Glaeser B (1984) Ecodevelopment: concepts, projects, strategies. Pergamon Press, New York

Gómez-Baggethun E, Naredo JM (2015) In search of lost time: the rise and fall of limits to growth in international sustainability policy. Sustain Sci 10:385-395. https://doi.org/10.1007/s11625015-0308-6

Goodland R (1995) The concept of environmental sustainability. Annu Rev Ecol Syst 26:1-24

Goodland R, Daly H (1996) Environmental sustainability: universal and non-negotiable. Ecol Appl 6:1002-1017

Grober U (2012) Sustainability: a cultural history, translated. Green Books, Totnes

Hammond A, Adriaanse A, Rodenburg E et al (1995) Environmental Indicators: a systematic approach to measuring and reporting on environmental policy performance in the context of sustainable development. World Resources Institute, Washington

Hancock T (1993) Health, human development and the community ecosystem: three ecological models. Health Promot Int 8:41-47. https://doi.org/10.1093/heapro/8.1.41

Hicks N, Streeten P (1979) Indicators of development: the search for a basic needs yardstick. World Dev 7:567-580. https://doi.org/10. 1016/0305-750X(79)90093-7

Hill RC, Bowen PA (1997) Sustainable construction: principles and a framework for attainment. Constr Manag Econ 15:223-239. https://doi.org/10.1080/014461997372971

Hirsch F (1995) Social limits to growth, 2nd edn. Routledge, London

Holmberg J (1992) Policies for a small planet: from the international institute for environment and development. Earthscan, London

Huckle J (1991) Education for sustainability: assessing pathways to the future. Aust J Environ Educ 7:43-62. https://doi.org/10.1017/ S0814062600001853

ILO (1976) Employment, growth and basic needs: a one-world problem. Praeger, New York

IUCN (1996) Barometer of sustainability: what it's for and how to use it. IUCN, Gland

IUCN (2004) The IUCN programme 2005-2008. many voices, one earth. IUCN, Gland

IUCN (1997) Proceedings. World conservation congress 13-23 October 1996 Montreal. IUCN, Gland

IUCN, UNEP, WWF (1980) World conservation strategy. Living resource conservation for sustainable development. IUCN, Gland

IUCN, UNEP, WWF (1991) Caring for the earth. a strategy for sustainable living. IUCN, Gland

Jacobs P, Gardner J, Munro DA (1987) Sustainable and equitable development: an emerging paradigm. Conservation with equity: strategies for sustainable development. IUCN, Gland, pp 17-29 
Johnston P, Everard M, Santillo D, Robèrt K-H (2007) Reclaiming the definition of sustainability. Environ Sci Pollut Res 14:60-66. https://doi.org/10.1065/espr2007.01.375

Jordan A, Voisey H (1998) The "rio process": the politics and substantive outcomes of "earth summit II". Glob Environ Change 8:93-97. https://doi.org/10.1016/S0959-3780(97)000241

Kajikawa Y, Tacoa F, Yamaguchi K (2014) Sustainability science: the changing landscape of sustainability research. Sustain Sci 9:431-438. https://doi.org/10.1007/s11625-014-0244-x

Kates RW, Clark WC, Corell R et al (2001) Sustainability science. Science 292:641-642 (80-)

Kidd CV (1992) The evolution of sustainability. J Agric Environ Ethics 5:1-26. https://doi.org/10.1007/BF01965413

Komiyama H, Takeuchi K (2006) Sustainability science: building a new discipline. Sustain Sci 1:1-6. https://doi.org/10.1007/ s11625-006-0007-4

Lamberton G (2005) Sustainability accounting - A brief history and conceptual framework. Account Forum 29:7-26. https://doi.org/ 10.1016/j.accfor.2004.11.001

Lehtonen M (2004) The environmental-social interface of sustainable development: capabilities, social capital, institutions. Ecol Econ 49:199-214. https://doi.org/10.1016/j.ecolecon.2004.03.019

Lélé SM (1991) Sustainable development: a critical review. World Dev 19:607-621. https://doi.org/10.1016/0305-750X(91)90197-

Lozano R (2008) Envisioning sustainability three-dimensionally. J Clean Prod 16:1838-1846. https://doi.org/10.1016/j.jclepro. 2008.02.008

Lumley S, Armstrong P (2004) Some of the nineteenth century origins of the sustainability concept. Environ Dev Sustain 6:367-378. https://doi.org/10.1023/B:ENVI.0000029901.02470. a7

Macnaghten P, Jacobs M (1997) Public identification with sustainable development. Glob Environ Change 7:5-24. https://doi.org/10. 1016/S0959-3780(96)00023-4

Martinez-Alier J (2015) Ecological economics. In: Wright JD (ed) International encyclopedia of the social \& behavioral sciences, 2nd edn. Elsevier, Amsterdam, pp 851-864

Martínez-Alier J (1995) The environment as a luxury good or "too poor to be green"? Ecol Econ 13:1-10. https://doi.org/10.1016/ 0921-8009(94)00062-Z

Meadows DL (1977) Alternatives to growth-I: a search for sustainable futures. Ballinger Publishing Company, Boston

Meadows DH, Meadows DL, Randers J, Behrens WW (1972) The limits to growth. Universe Books, New York

Mebratu D (1998) Sustainability and sustainable development: historical and conceptual review. Environ Impact Assess Rev 18:493-520. https://doi.org/10.1016/S0195-9255(98)00019-5

Milbrath LW (1989) Envisioning a sustainable society: learning our way out. State University of New York Press, Albany

Milne MJ (1996) On sustainability; the environment and management accounting. Manag Account Res 7:135-161. https://doi.org/10. 1006/mare.1996.0007

Milne MJ, Gray R (2013) W(h)ither Ecology? The triple bottom line, the global reporting initiative, and corporate sustainability reporting. J Bus Ethics 118:13-29. https://doi.org/10.1007/ s10551-012-1543-8

Mishan EJ (1977) The economic growth debate: an assessment. Allen \& Unwin, London

Moldan B, Janoušková S, Hák T (2012) How to understand and measure environmental sustainability: indicators and targets. Ecol Indic 17:4-13. https://doi.org/10.1016/j.ecolind.2011.04. 033

Mori K, Christodoulou A (2012) Review of sustainability indices and indicators: towards a new city sustainability index (CSI).
Environ Impact Assess Rev 32:94-106. https://doi.org/10.1016/ j.eiar.2011.06.001

Munasinghe M (1993) Environmental economics and sustainable development. The World Bank, Washington

Norman W, Macdonald C (2004) Getting to the bottom of "triple bottom line”. Bus Ethics Q 14:243-262. https://doi.org/10.1016/ j.ijpe.2012.01.035

O'Riordan T (1985) Research policy and review 6. Future directions for environmental policy. Environ Plan A 17:1431-1446. https:// doi.org/10.1068/a171431

OECD (2000) Towards sustainable development. Indicators to measure progress. OECD Publications, Paris

OECD (2004) Sustainable development in OECD countries. Getting the policies right. OECD Publications, Paris

Passet R (1979) L'économique et le vivant. Payot, Paris

Pezzey J (1992) Sustainable development concepts: an economic analysis. The World Bank, Washington

Pirages D (1977) The sustainable society: implications for limited growth. Praeger, New York

Pope J, Annandale D, Morrison-Saunders A (2004) Conceptualising sustainability assessment. Environ Impact Assess Rev 24:595-616. https://doi.org/10.1016/j.eiar.2004.03.001

Redclift MR (1987) Sustainable development: exploring the contradictions. Routle, London

Redclift M (2005) Sustainable development (1987-2005): an oxymoron comes of age. Sustain Dev 13:212-227. https://doi.org/ $10.1002 / \mathrm{sd} .281$

Rome A (2003) "Give earth a chance": the environmental movement and the sixties. J Am Hist 90:525-554. https://doi.org/10.2307/3659443

Schoolman ED, Guest JS, Bush KF, Bell AR (2012) How interdisciplinary is sustainability research? Analyzing the structure of an emerging scientific field. Sustain Sci 7:67-80. https://doi.org/10. 1007/s11625-011-0139-z

Seers D (1969) The meaning of development. Inst Dev Stud Commun 44:1-26

Sneddon CS (2000) "Sustainability" in ecological economics, ecology and livelihoods: a review. Prog Hum Geogr 24:521-549. https://doi.org/10.1191/030913200100189076

Soini K, Birkeland I (2014) Exploring the scientific discourse on cultural sustainability. Geoforum 51:213-223. https://doi.org/10. 1016/j.geoforum.2013.12.001

Spangenberg JH, Pfahl S, Deller K (2002) Towards indicators for institutional sustainability: lessons from an analysis of Agenda 21. Ecol Indic 2:61-77. https://doi.org/10.1016/S1470$160 X(02) 00050-X$

Stirling A (1999) The appraisal of sustainability: some problems and possible responses. Local Environ 4:111-135. https://doi.org/10. 1080/13549839908725588

Stivers RL (1976) The sustainable society: ethics and economic growth. Westminster Press, Philadelphia

Streeten P, Burki SJ (1978) Basic needs: some issues. World Dev 6:411-421. https://doi.org/10.1016/0305-750X(78)90116-X

Tanguay GA, Rajaonson J, Lefebvre J-F, Lanoie P (2010) Measuring the sustainability of cities: an analysis of the use of local indicators. Ecol Indic 10:407-418. https://doi.org/10.1016/j. ecolind.2009.07.013

The Ecology Party (1975) Manifesto for a sustainable society. The Ecology Party, Leeds

Thompson PB (2017) The spirit of the soil: agriculture and environmental ethics, 2nd edn. Routledge, New York

Tulloch L (2013) On science, ecology and environmentalism. Policy Future Educ 11:100-114. https://doi.org/10.2304/pfie.2013.11.1. 100

Tulloch L, Neilson D (2014) The neoliberalisation of sustainability. citizenship. Soc Econ Educ 13:26-38. https://doi.org/10.2304/ csee.2014.13.1.26 
Turcu C (2012) Re-thinking sustainability indicators: local perspectives of urban sustainability. J Environ Plan Manag 56:1-25. https://doi.org/10.1080/09640568.2012.698984

UN (1987) Report of the world commission on environment and development: our common future. Oxford University Press, Oxford

UN (1992) Agenda 21. United Nations, New York

UN (1995) Workshop on indicators of sustainable development for decision-making. Commission on sustainable development third session (E/CN.17/1995/32). United Nations, New York

UN (1996) Indicators of sustainable development framework and methodologies. United Nations, New York

UN (1997) Overall progress achieved since the United Nations conference on environment and development. Commission on sustainable development fifth session (E/CN.17/1997/2). United Nations, New York

UN (1998) Commission on sustainable development. Report on the sixth session (E/CN.17/1998/20). United Nations, New York

UN (2001a) Indicators of sustainable development: framework and methodologies. Commission on sustainable development ninth session (DESA/DSD/2001/3). United Nations, New York

UN (2001b) Road map towards the implementation of the United Nations Millennium Declaration. Report of the SecretaryGeneral (A/56/326). United Nations, New York

UN (2002) Report of the world summit on sustainable development (A/CONF.199/20). United Nations, New York

UN (2007) Indicators of sustainable development: guidelines and methodologies, 3rd edn. United Nations, New York

UN (2012a) The future we want. Resolution adopted by the general assembly on 27 July 2012 (A/RES/66/288). United Nations, New York
UN (2012b) Report of the United Nations conference on sustainable development (A/CONF.216/16). United Nations, New York

UN (2015) Transforming our world: the 2030 Agenda for sustainable development. Resolution adopted by the general assembly on 25 September 2015 (A/RES/70/1). United Nations, New York

Upham P (2000) An assessment of the natural step theory of sustainability. J Clean Prod 8:445-454. https://doi.org/10.1016/ S0959-6526(00)00012-3

Valentin A, Spangenberg JH (2000) A guide to community sustainability indicators. Environ Impact Assess Rev 20:381-392. https://doi.org/10.1016/S0195-9255(00)00049-4

Van Der Heijden H-A (1999) Environmental movements, ecological modernisation and political opportunity structures. Env Polit 8:199-221. https://doi.org/10.1080/09644019908414444

Vos RO (2007) Defining sustainability: a conceptual orientation. J Chem Technol Biotechnol 82:334-339. https://doi.org/10. $1002 /$ jctb. 1675

Waas T, Hugé J, Verbruggen A, Wright T (2011) Sustainable development: a bird's eye view. Sustainability 3:1637-1661. https://doi.org/10.3390/su3101637

Warde P (2011) The invention of sustainability. Mod Intellect Hist 8:153-170. https://doi.org/10.1017/S1479244311000096

Woodhouse EJ (1972) Re-visioning the future of the third world: an ecological perspective on development. World Polit 25:1-33. https://doi.org/10.2307/2010429

Yunlong C, Smit B (1994) Sustainability in agriculture: a general review. Agric Ecosyst Environ 49:299-307. https://doi.org/10. 1016/0167-8809(94)90059-0

Zijp MC, Heijungs R, van der Voet E et al (2015) An identification key for selecting methods for sustainability assessments. Sustainability 7:2490-2512. https://doi.org/10.3390/su7032490 